\title{
The Effect of Acute Iodide Depletion on Thyroid Function in $\operatorname{Man} *$
}

\author{
Russell M. Barakat and Sidney H. Ingbar $\dagger$ \\ (From the Thorndike Memorial Laboratory and the Second and Fourth [Harvard] Medical \\ Services, Boston City Hospital, and the Department of Medicine, Harvard \\ Medical School, Boston, Mass.)
}

In addition to a variety of effects on the intermediary metabolism of the thyroid gland, and perhaps as a consequence thereof, the thyrotropic hormone of the anterior pituitary (TSH) induces thyroidal hypertrophy, hyperplasia, and hypervascularity and stimulates most, if not all, phases of iodine metabolism leading to the synthesis and secretion of thyroid hormone $(1,2)$. Decreases in thyroid cell size, blood flow, and hormone synthesis occur in the absence of TSH stimulation.

For the foregoing reasons, it is generally agreed that TSH is the major regulator of thyroid structure and function. Nevertheless, there is growing evidence that the thyroid gland contains mechanisms for modifying its own function. Thus, in hypophysectomized rats, dietary iodine restriction increases thyroid uptake of $\mathrm{I}^{121}$ and may enhance mean acinar cell height $(3,4)$. Furthermore, in hypophysectomized rats given either no $\mathrm{TSH}$ or constant doses of this hormone, the activity of the thyroid iodide-transport mechanism varies inversely with the glandular content of organic iodine (5-10). The effects of such autoregulatory mechanisms in the absence of TSH are relatively small; their most important role probably stems from their ability to modify the glandular response to trophic stimulation (8-10).

There are, apparently, no data as to whether similar autoregulatory phenomena occur in the human thyroid. In normal subjects, as much as $2 \mathrm{mg}$ of iodide can be acutely administered without appreciably changing the percentage uptake

* Submitted for publication December 21, 1964; accepted March 4, 1965.

Supported in part by research grant AM-00267 from the National Institute of Arthritis and Metabolic Diseases, Bethesda, Md.

$\dagger$ Address requests for reprints to Dr. Sidney H. Ingbar, Thorndike Memorial Laboratory, Boston City Hospital, 818 Harrison Avenue, Boston, Mass. 02118. of concomitantly administered $\mathrm{I}^{131}$ (11). When supplements of stable iodide are chronically administered, on the other hand, $I^{\text {ras }}$ uptake declines $(12,13)$. It is not known, however, whether the decrease in thyroid iodide clearance rate that this decrease in $\mathrm{I}^{131}$ uptake reflects is mediated by changes in the secretion of TSH or by changes within the thyroid gland itself. The converse situation, chronic deficiency of dietary iodine, has been extensively studied in man; its consequent thyroid hyperfunction is thoroughly documented (14-16). Here too, however, it is uncertain whether these functional changes originate entirely, or only partially, within the pituitary.

This paucity of data concerning thyroid autoregulation in man doubtless stems from the relative rarity of patients with hypopituitarism and from the difficulty in accurately assessing in vivo the low level of thyroid function that occurs when hypopituitarism does exist. In the present studies, therefore, efforts were made to produce iodide depletion in normal patients under conditions in which it would be unlikely that changes in the secretion of TSH could mediate any changes in thyroid function that might ensue. By methods described below, acute depletion of extracellular iodide was achieved and was found to be associated with increased thyroid function. A preliminary report of these findings has appeared in abstract form (17).

\section{Methods}

Patient material. Studies were performed in eight patients being cared for on the wards or in the Endocrine Outpatient Clinic of the Boston City Hospital. Four patients had no thyroid disease. One had a nontoxic goiter and another was euthyroid with Graves' disease in remission. One patient had moderately severe and another very severe diffuse toxic goiter. Pertinent clinical and laboratory data are recorded in Table $I$. 
TABLE I

The effect of acute depletion of extracellular iodide induced by a low-iodine

\begin{tabular}{|c|c|c|c|c|c|c|c|c|c|c|c|}
\hline \multirow{2}{*}{$\begin{array}{l}\text { Name } \\
\text { Age } \\
\text { Sex }\end{array}$} & \multirow[b]{2}{*}{ Diagnosis } & \multirow{2}{*}{$\begin{array}{c}\text { Exp. } \\
\text { no. }\end{array}$} & \multicolumn{3}{|c|}{ Serum $\mathrm{I}^{-}$} & \multicolumn{3}{|c|}{$\begin{array}{l}\text { Thyroid I- trans- } \\
\text { fer rate }\end{array}$} & \multicolumn{3}{|c|}{ Thyroid I'27 accumulation } \\
\hline & & & a & b & c & $\mathbf{a}$ & b & c & a & b & c \\
\hline & & & \multicolumn{3}{|c|}{$\mu \mathrm{g} / 100 \mathrm{ml}$} & \multicolumn{3}{|c|}{$m l / m i n$} & \multicolumn{3}{|c|}{$\mu g / 24$ hours } \\
\hline$\underset{36,}{\mathrm{~J}}, \mathrm{M}$ & Euthyroid & 1 & 0.68 & 0.40 & 0.29 & 25 & 33 & 40 & 242 & 189 & 168 \\
\hline$\stackrel{\mathrm{O} .}{\mathrm{P}}, \dot{\mathrm{M}}$ & Euthyroid & $\begin{array}{l}2 \\
2 \mathrm{~A}\end{array}$ & $\begin{array}{l}0.30 \\
0.30\end{array}$ & & $\begin{array}{l}0.15 \\
0.72\end{array}$ & $\begin{array}{l}35 \\
37\end{array}$ & & $\begin{array}{l}67 \\
36\end{array}$ & $\begin{array}{l}152 \\
160\end{array}$ & & $\begin{array}{l}145 \\
373\end{array}$ \\
\hline $\begin{array}{l}\text { G. } \mathrm{K} . \\
26, \mathbf{M}\end{array}$ & Euthyroid & $\begin{array}{l}3 \\
3 \mathrm{~A}\end{array}$ & $\begin{array}{l}0.73 \\
0.49\end{array}$ & 0.45 & $\begin{array}{l}0.16 \\
0.62\end{array}$ & $\begin{array}{l}27 \\
31\end{array}$ & 39 & $\begin{array}{l}31 \\
25\end{array}$ & $\begin{array}{l}285 \\
219\end{array}$ & 249 & $\begin{array}{r}72 \\
224\end{array}$ \\
\hline $\begin{array}{l}\text { R. C. } \\
\text { 3i, }\end{array}$ & Euthyroid & $\begin{array}{l}4 \\
4 \mathrm{~A}\end{array}$ & $\begin{array}{l}0.40 \\
0.35\end{array}$ & 0.32 & $\begin{array}{l}0.25 \\
1.30\end{array}$ & $\begin{array}{r}7 \\
12\end{array}$ & 16 & $\begin{array}{l}16 \\
13\end{array}$ & $\begin{array}{l}43 \\
58\end{array}$ & 73 & $\begin{array}{r}53 \\
256\end{array}$ \\
\hline A. B. & Nontoxic goiter & 5 & 0.65 & & 0.24 & 11 & & 16 & 108 & & 47 \\
\hline $\begin{array}{l}\text { N. S. } \\
\mathbf{3 0}, \overrightarrow{\mathrm{F}}\end{array}$ & $\begin{array}{l}\text { Treated } \\
\text { thyrotoxicosis }\end{array}$ & 6 & 0.21 & & 0.14 & 43 & & 62 & 130 & & 125 \\
\hline $\begin{array}{l}\text { H. D. } \\
56, \mathrm{~F}\end{array}$ & Thyrotoxicosis & 7 & 0.34 & 1.23 & 0.19 & 76 & 75 & 105 & 375 & 250 & 287 \\
\hline$\underset{24}{\mathrm{C}}, \mathrm{J}_{\dot{\mathrm{F}}}$ & Thyrotoxicosis & 8 & 0.22 & & 0.16 & 719 & . & 760 & 2,278 & & 1,728 \\
\hline \multicolumn{3}{|c|}{$\begin{array}{c}\text { Mean difference (Test a-Test b) } \\
\text { SEMD } \\
\text { n } \\
\text { p }\end{array}$} & \multicolumn{3}{|c|}{$\begin{array}{l}-0.19 \\
0.054 \\
4 \\
<0.05\end{array}$} & \multicolumn{3}{|c|}{$\begin{array}{l}+7 \\
2.8 \\
4 \\
\mathrm{NS}\end{array}$} & \multicolumn{3}{|c|}{$\begin{array}{l}-46 \\
31.9 \\
N^{4}\end{array}$} \\
\hline \multicolumn{3}{|c|}{$\begin{array}{c}\text { Mean difference (Test a-Test c) } \\
\text { SEMD } \\
\text { n } \\
\text { p }\end{array}$} & \multicolumn{3}{|c|}{$\begin{array}{l}-0.24 \\
0.058 \\
8 \\
<0.01\end{array}$} & \multicolumn{3}{|c|}{$\begin{array}{c}+19 \\
4.8 \\
8 \\
<0.01\end{array}$} & \multicolumn{3}{|c|}{$\begin{array}{l}-123 \\
65.8 \\
\text { NS }\end{array}$} \\
\hline
\end{tabular}

* $\mathrm{PBI}=$ protein-bound iodine; $\mathrm{U} / \mathrm{P}=$ urine/plasma; $\mathrm{SEMD}=$ standard error of the mean difference. Test a, control or prediuresis test test $\mathrm{b}$, during mannitol diuresis; test $c$, postdiuresis test performed morning after mannitol infusion. In experiments $2 \mathrm{~A}, 3 \mathrm{~A}$, and $4 \mathrm{~A}, 800 \mathrm{gg}$ iodide added to mannitol infusion; results of these experiments are not included in statistical tabulations.

Induction of iodide depletion. All patients were studied on a metabolic ward. Depletion of extracellular iodide was produced by a combination of two methods. The first was the provision of a diet low in iodine. This consisted principally of milk that had been passed at least three times over an anion exchange column (IRA-400, chloride cycle). Analyses of untreated milk revealed an iodine content ranging between 12 and $13 \mu \mathrm{g}$ per $100 \mathrm{ml}$. During passage through the column, the iodine content was reduced to $2 \mu \mathrm{g}$ per $100 \mathrm{ml}$, all of which was protein bound. Patients were allowed free access to low-iodine milk and to distilled water throughout the study. Coffee, chocolate, and vanilla were also found to be low in iodine content. 1 These agents were therefore used to flavor the milk.

To intensify and hasten the depletion of iodide, advantage was taken of earlier observations indicating that the renal clearance of iodide is enhanced during osmotic diuresis (18). Patients were given a priming dose of 250 to $500 \mathrm{ml}$ of $20 \%$ solution of mannitol followed by a sustaining infusion of $400 \mathrm{~g}$ of mannitol delivered in a $10 \%$ solution over a period of 6 hours. The sustaining infusion also contained $50 \mathrm{mEq}$ of sodium chloride and, in some instances, 10 to $20 \mathrm{mEq}$ of potassium chloride per L. During osmotic diuresis, patients were allowed

1 As prepared in other liquids, coffee, chocolate, and vanilla were found to contribute 3.4 , essentially 0 , and $0.5 \mu \mathrm{g}$ iodine per $100 \mathrm{ml}$, respectively. free access to distilled water, low-iodine milk, or orange juice. In some instances, solutions of sodium and potassium chloride previously passed over the anion exchange column were administered orally during the mannitol infusion. By means of these supplements it was hoped to minimize or prevent depletion of water and electrolytes during the diuretic response.

Analyses of iodide kinetics. The kinetics of iodide metabolism were studied by methods previously described in detail (19). After having emptied their bladder, patients were given an intravenous injection of 20 to $50 \mu \mathrm{c}$ of inorganic $\mathrm{I}^{182}$. Epithyroid and thigh counts were performed, and urine and blood specimens were collected every 30 minutes thereafter for 3 hours. Twentyfour-hour thyroid $I^{121}$ uptakes were also determined. All measurements of radioactivity were related to the administered dose of $\mathrm{I}^{181}$. In the calculation of thyroid $I^{131}$ uptakes, radioactivity measured over the thigh was subtracted from that in the neck. After the initial test, residual radioactivity in the thyroid was determined before each subsequent test and was employed to correct determinations of thyroidal $\mathrm{I}^{131}$ uptake. In the measurement of the concentration of inorganic $\mathrm{I}^{181}$ in the serum of euthyroid subjects, total counts were employed during the first test; in subsequent tests, residual trichloroacetic acid (TCA)-precipitable $\mathrm{I}^{1 \mathrm{r}}$ was determined before injection of the new dose and was subtracted from values for serum $\mathrm{I}^{131}$ in subsequent samples. In patients 
TABLE I

diet and mannitol diuresis on the thyroidal accumulation of iodine in man*

\begin{tabular}{|c|c|c|c|c|c|c|c|c|c|c|c|c|c|c|c|c|c|}
\hline \multicolumn{3}{|c|}{$\begin{array}{c}\text { 3-Hour I181 } \\
\text { uptake }\end{array}$} & \multicolumn{3}{|c|}{$\begin{array}{l}\text { 24-Hour I131 } \\
\text { uptake }\end{array}$} & \multicolumn{3}{|c|}{ Serum PBI } & \multicolumn{3}{|c|}{$\begin{array}{l}\text { Renal I181 } \\
\text { clearance }\end{array}$} & \multicolumn{3}{|c|}{$\begin{array}{c}\text { Creatinine } \\
\text { clearance }\end{array}$} & \multicolumn{3}{|c|}{$\begin{array}{l}\text { Creatinine } \\
\mathrm{U} / \mathrm{P} \text { ratio }\end{array}$} \\
\hline $\mathbf{a}$ & b & c & $\mathbf{a}$ & b & c & a & b & c & $\mathrm{a}$ & b & c & $\mathbf{a}$ & b & c & $a$ & b & c \\
\hline \multicolumn{3}{|c|}{$\%$ dose } & \multicolumn{3}{|c|}{$\%$ dose } & \multicolumn{3}{|c|}{$\mu g / 100 \mathrm{ml}$} & \multicolumn{3}{|c|}{$m l / \min$} & \multicolumn{3}{|c|}{$m l / m i n$} & & & \\
\hline 16 & 15 & 23 & 30 & 34 & 39 & 6.4 & 5.2 & 6.4 & 58 & 82 & 55 & 166 & 151 & 142 & 11 & 4 & 16 \\
\hline $\begin{array}{l}24 \\
23\end{array}$ & & $\begin{array}{l}36 \\
23\end{array}$ & $\begin{array}{l}55 \\
55\end{array}$ & & $\begin{array}{l}65 \\
51\end{array}$ & 4.8 & & 5.6 & $\begin{array}{l}42 \\
43\end{array}$ & & $\begin{array}{l}48 \\
46\end{array}$ & $\begin{array}{l}194 \\
197\end{array}$ & & $\begin{array}{l}202 \\
169\end{array}$ & $\begin{array}{l}21 \\
19\end{array}$ & & $\begin{array}{l}17 \\
17\end{array}$ \\
\hline $\begin{array}{l}18 \\
18\end{array}$ & 21 & $\begin{array}{l}24 \\
17\end{array}$ & $\begin{array}{l}36 \\
39\end{array}$ & 42 & $\begin{array}{l}46 \\
32\end{array}$ & $\begin{array}{l}5.6 \\
5.8\end{array}$ & 4.8 & $\begin{array}{l}6.2 \\
6.1\end{array}$ & $\begin{array}{l}51 \\
39\end{array}$ & 62 & $\begin{array}{l}40 \\
39\end{array}$ & $\begin{array}{l}186 \\
182\end{array}$ & 142 & $\begin{array}{l}150 \\
186\end{array}$ & $\begin{array}{l}23 \\
19\end{array}$ & 6 & $\begin{array}{l}22 \\
21\end{array}$ \\
\hline $\begin{array}{r}7 \\
10\end{array}$ & 11 & $\begin{array}{l}14 \\
11\end{array}$ & $\begin{array}{l}18 \\
23\end{array}$ & 23 & $\begin{array}{l}28 \\
23\end{array}$ & $\begin{array}{l}4.6 \\
4.0\end{array}$ & 4.2 & $\begin{array}{l}4.6 \\
4.2\end{array}$ & $\begin{array}{l}39 \\
30\end{array}$ & 64 & $\begin{array}{l}40 \\
31\end{array}$ & $\begin{array}{l}128 \\
123\end{array}$ & 129 & $\begin{array}{l}128 \\
132\end{array}$ & $\begin{array}{l}10 \\
10\end{array}$ & 7 & $\begin{array}{l}11 \\
10\end{array}$ \\
\hline 11 & & 18 & 26 & & 38 & 5.6 & & 4.8 & 42 & & 38 & 123 & & 127 & 13 & & 12 \\
\hline 31 & & 37 & 48 & & 58 & 5.8 & & 5.4 & 46 & & 48 & 160 & & 160 & 18 & & 34 \\
\hline 51 & 39 & 66 & 70 & 78 & 86 & 8.8 & 9.0 & 8.8 & 23 & 33 & 23 & 111 & 113 & 120 & 19 & 5 & 18 \\
\hline 86 & & 98 & 84 & & 95 & 9.0 & & 9.2 & 47 & & 35 & 230 & & 217 & 19 & & 18 \\
\hline & $\begin{array}{c}-2 \\
3.7 \\
4 \\
\mathrm{NS}\end{array}$ & & & $\begin{array}{l}+6 \\
0.9 \\
4 \\
0.02\end{array}$ & & & $\begin{array}{c}-0.5 \\
0.3 \\
4 \\
\mathrm{NS}\end{array}$ & & & $\begin{array}{c}+18 \\
4.1 \\
4 \\
<0.05\end{array}$ & & & $\begin{array}{c}-14 \\
\quad 9.5 \\
\mathrm{NS}^{4}\end{array}$ & & & $\begin{array}{c}-10 \\
3.2 \\
4 \\
0.05\end{array}$ & \\
\hline & $\begin{array}{c}+9 \\
1.1 \\
8 \\
<0.01\end{array}$ & & & $\begin{array}{c}+11 \\
0.8 \\
8 \\
<0.01\end{array}$ & & & $\begin{array}{c}+0.1 \\
0.5 \\
8 \\
\mathrm{NS}^{8}\end{array}$ & & & $\begin{array}{c}-3 \\
2.0 \\
\mathrm{NS}^{8}\end{array}$ & & & $\begin{array}{c}-6 \\
\quad 5.8 \\
\mathrm{NS}^{8}\end{array}$ & & & $\begin{array}{c}+2 \\
\stackrel{2.2}{8} \\
\mathrm{NS}^{8}\end{array}$ & \\
\hline
\end{tabular}

with thyrotoxicosis, TCA-soluble $\mathrm{I}^{131}$ was determined in all samples and was considered to represent serum inorganic $\mathrm{I}^{131}$.

From such measurements, thyroid $\mathrm{I}^{131}$ transfer and clearance rates, as well as renal $\mathrm{I}^{131}$ clearance rates, could be calculated according to methods described elsewhere (19-22)..$^{2}$ Serum inorganic $I^{127}$ concentration was calculated by the indirect method of Stanley, based upon the renal excretion of $I^{127}$ and the renal clearance of $I^{131}$

2 The method employed for assessing the kinetics of thyroid $I^{131}$ accumulation purports to measure the rate of transfer of plasma iodide into thyroid organic iodine. Clearance measurements, on the other hand, measure the rate of removal of plasma iodide into total thyroid iodine. Although certain of the assumptions underlying the method for measuring thyroid Im transfer rates were criticized some time ago (23), more recent observations by other workers tend implicitly to support the theoretical validity of the method herein employed (24-26). A lengthy discussion of this evidence is beyond the scope of this report. Suffice it to say that thyroid $I^{181}$ transfer rates herein presented agreed closely and predictably with estimates of thyroid clearance rates obtained from the same data by other methods $(20,21)$. Thus, the sense of our data would be in no way altered if thyroid clearance, rather than transfer, rates were employed to assess the effects of acute iodide depletion. In the discussion that follows, the two terms may be considered interchangeable.
(27). Thyroidal $I^{127}$ accumulation rates were calculated as the product of thyroid $\mathrm{I}^{131}$ transfer rates and the calculated concentration of inorganic $\mathrm{I}^{127}$ in the serum.

Analyses for stable iodine $\left(\mathrm{I}^{127}\right)$ in foods and urine and for protein-bound iodine in the serum were performed by a modification of the method of Zak (28). ${ }^{3}$

Analysis for the statistical significance of the changes in iodine metabolism was performed by the paired $t$ test, as described by Snedecor (29).

Experimental design. Patients were admitted to a metabolic ward and were given a standard hospital diet. Several days later kinetics of $\mathrm{I}^{131}$ metabolism were assessed (control, "prediuresis" test). On the morning of the first or second day thereafter, patients were placed on the low-iodine regimen. On the morning of the second day of this diet, mannitol infusion was begun in all patients. In four of the eight patients, a second test of iodide kinetics ("diuretic" test) was carried out during the last 3 hours of mannitol infusion, while osmotic diuresis was well maintained. On the morning of the day following mannitol infusion, the patients having continued on the low-iodine diet, a third assessment of iodide kinetics ("postdiuresis" test) was carried out in all eight patients.

Four of the patients were studied again after more than a week on a normal diet. Here, the entire experimental procedure was repeated, except that $800 \mu \mathrm{g}$ of potassium iodide was added to the sustaining infusion

3 Analyses performed in the Boston Medical Laboratory, Boston, Mass. 
of mannitol. In three patients, iodide kinetics were assessed during control and postdiuretic periods. In the fourth patient, thyroid and renal clearances were not measured; only $\mathrm{I}^{131}$ accumulation curves were obtained during control and postdiuretic tests.

\section{Results}

Findings in each of the patients are shown in Table I and represent the averages of values obtained during the last five clearance periods of each test.

Renal clearance of $I^{131}$. During control tests, renal clearances of $I^{131}$ in all patients were within normal limits (mean, $42 \mathrm{ml}$ per minute; range, 23 to 58), as were clearances of endogenous creatinine. Mannitol induced a brisk osmotic diuresis, as evidenced by both increased rates of urine flow and decreased creatinine urine/plasma (U/P) ratios. During osmotic diuresis, $\mathrm{I}^{131}$ clearances increased in all four patients tested. The percentage increase was variable, however, ranging between 22 and $54 \%$ and averaging $42 \%$. During the postdiuretic phase, renal clearances of $\mathrm{I}^{131}$ in all patients were very similar to those found during the control period.

Serum inorganic $I^{127}$. During the control test, concentrations of inorganic iodide in the serum of nonthyrotoxic patients ranged between 0.21 and 0.73 and averaged $0.44 \mu \mathrm{g}$ per $100 \mathrm{ml}$. Values in the two actively thyrotoxic patients were 0.34 and $0.22 \mu \mathrm{g}$ per $100 \mathrm{ml}$. In tests performed during mannitol diuresis, values for serum inorganic iodide decreased in all four patients, the mean declining from 0.54 to $0.35 \mu \mathrm{g}$ per $100 \mathrm{ml}$. For the group of patients as a whole, marked decreases in serum iodide concentration were evident during the postdiuretic test; values averaged $0.20 \mu \mathrm{g}$ per $100 \mathrm{ml}$ at this time.

Thyroid $I^{131}$ transfer and clearance rates. Thyroid iodide transfer rates were normal in the four patients without thyroid disease and in the one patient with nontoxic goiter (mean, $21 \mathrm{ml}$ per minute; range, 7 to 35 ), were marginally increased in the patient with treated thyrotoxicosis, and were distinctly increased in patients with active thyrotoxicosis (19). In the four tests carried out during the diuretic phase, thyroid transfer rates increased by from 32 to $45 \%$ in the three euthyroid subjects, but remained unchanged in the patient with moderate thyrotoxicosis.
As compared to values obtained during control tests, thyroid transfer rates during the postdiuresis tests were increased in all eight patients. The increase averaged 54\% (range, 6 to 129\%) for the group as a whole and was highly significant statistically $(p<0.01)$. The smallest percentage increase in thyroid transfer rate was observed in the patient with severe thyrotoxicosis; here, however, the absolute increase in transfer rate (41 $\mathrm{ml}$ per minute) was greater than that seen in the other patients.

Thyroid $\mathrm{I}^{131}$ clearance rates agreed closely with transfer rates during all three phases of the studies.

Thyroid $I^{127}$ accumulation. The rate of $\mathrm{I}^{127}$ accumulation by the thyroid was calculated as the product of the plasma iodide concentration and the thyroid iodide transfer rate. Control values in the six nonthyrotoxic patients averaged 160 $\mu \mathrm{g}$ per 24 hours. Similarly derived values in the literature vary widely. Those found in the present studies exceed those reported by some other workers $(30,31)$, but are within the range found by still others in euthyroid patients $(12,15,27$, $32)$. In the two thyrotoxic patients, control values were 375 and $2,278 \mu \mathrm{g}$ per 24 hours, respectively. $I^{127}$ accumulation rates decreased in three of four patients during infusion of mannitol and in seven of eight patients during the postdiuretic test. Because of wide variation in the magnitude of the decrease, however, the change was not statistically significant according to the paired $t$ test.

Thyroid $I^{131}$ uptakes. Although thyroid $\mathrm{I}^{131}$ uptakes at 3 hours were decreased in two of four patients during the diuretic test, uptakes at 24 hours were increased in all (average increase, $17 \%)$. This change was statistically significant.

During postdiuretic tests, both 3- and 24-hour thyroid $I^{131}$ uptakes increased in all patients. This change was statistically significant at both time periods $(\mathrm{p}<0.01)$.

Serum protein-bound iodine. In the four patients in whom tests were performed during mannitol diuresis, values for serum protein-bound iodine (PBI) tended to be somewhat lower than control values, probably as a result of expansion of the plasma volume. The change in PBI, which averaged $0.5 \mu \mathrm{g}$ per $100 \mathrm{ml}$, was not significant according to the paired $t$ test. By the following morning, during postdiuresis tests, values for se- 
rum PBI in all patients were essentially the same as those found during control tests.

Effects of supplementing mannitol infusions with iodide. When, in repeat experiments, mannitol infusions were supplemented with $800 \mu \mathrm{g}$ of sodium iodide, the decline in plasma iodide concentration evident during previous postdiuresis tests was prevented. Indeed, iodide concentrations were moderately increased. In contrast to results obtained in the previous tests in which iodide was not administered, no change in thyroid iodine metabolism was seen. Thyroid $\mathrm{I}^{131}$ accumulation curves were remarkably similar to those found during prediuresis tests, as were thyroidal iodide clearances (Figure 1).

\section{Discussion}

The present studies were undertaken in an effort to determine whether there exist within the human thyroid gland intrinsic mechanisms that alter the function of the gland in response to acute reduction in the plasma iodide concentration. To do so, it was necessary to devise a method for acutely depleting iodide in body stores. Theoretically, iodide stores could be depleted by total fasting. Since the iodide pool is normally small (approximately $90 \mu \mathrm{g}$ ) in relation to the normal dietary iodine intake (150 to $200 \mu \mathrm{g}$ daily), it follows that the extracellular iodide pool normally turns over quite rapidly. This is reflected in a disappearance rate of labeled iodide that normally averages approximately $20 \%$ per hour (19). Thus, within a 24-hour period, the plasma iodide would be expected to decrease to approximately one-seventh of its initial value, provided that sources of replenishment were removed. Even with complete fasting, however, some replenishment of iodide stores would occur, since peripheral degradation of thyroid hormone liberates at least $50 \mu \mathrm{g}$ of iodide daily into the extracellular iodide pool $(33,34)$. Furthermore, in thyrotoxic patients, in whom hormonal degradation is greatly increased, iodide arising from this source would exceed the dietary intake, and fasting, therefore, would be relatively less effective $(33,34)$. In addition to iodide liberated by the degradation of thyroid hormone peripherally, it is likely that at least the hyperactive thyroid itself liberates substantial amounts of nonthyroxine iodine into the

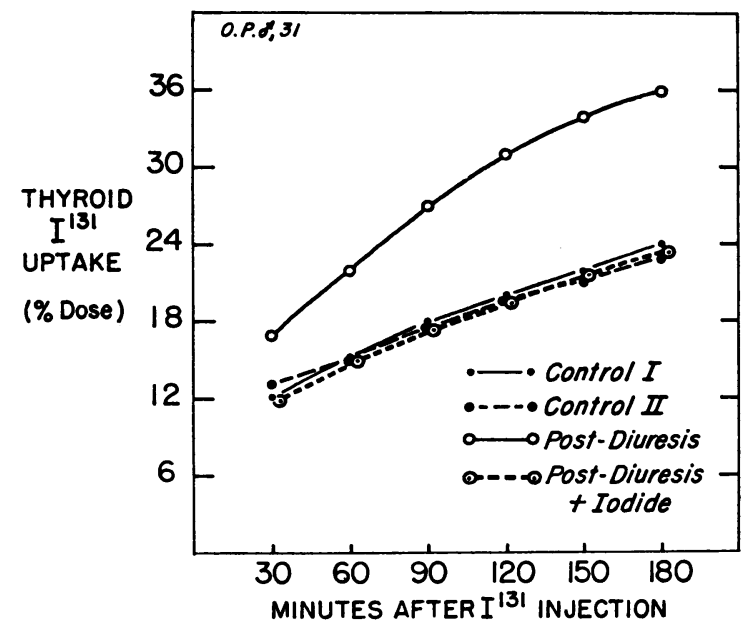

Fig. 1. The effect of acute iodide Depletion on THE THYROID ACCUMULATION OF INTRAVENOUSLY ADMINISTERED INORGANIC $\mathrm{I}^{131}$. Postdiuresis tests performed the day after infusion of mannitol. In test designated as "postdiuresis + iodide," $800 \mu \mathrm{g}$ of sodium iodide had been added to the mannitol infusion. This test and its control (control II) performed 10 days after completion of the other two studies.

plasma $(33,35-37)$. These would provide a further source of replenishment upon their deiodination. Thus, a short period of fasting might not suffice to decrease plasma iodide concentrations appreciably. Moreover, total fasting would be expected to induce a variety of endocrine and metabolic alterations, other than iodide depletion, which might themselves affect thyroid function. ${ }^{4}$

In the present studies, therefore, alternative methods of depleting iodide stores were sought. Patients were given foods either naturally poor in iodine or depleted thereof by treatment with anion exchange resin. In addition, vigorous osmotic diuresis was employed to enhance renal clearance of iodide and to increase, thereby, the depletion of iodide induced by dietary restriction. These measures were highly effective. Estimates of the concentration of iodide in plasma were decreased in all four patients studied during mannitol diuresis and had decreased even further by the time of the postdiuresis test. In the remain-

\footnotetext{
4 These doubts concerning the efficacy of simple fasting as a means of inducing uncomplicated iodide depletion have recently been verified by studies which have demonstrated that a total fast of 1 to 3 days duration not only fails to decrease the iodide concentration in plasma, but also leads to decreases in both thyroid iodide clearance rate and absolute iodine accumulation (38).
} 
ing four patients, too, values for the plasma iodide concentration below those obtained in control tests were evident during postdiuresis tests.

Several indexes provided evidence that thyroid function had increased as a consequence of the iodide depletion procedures carried out. Although not evident in one patient with thyrotoxicosis, increased thyroid transfer and clearance rates were observed in each of three euthyroid patients during the diuresis test. During this test, the 3-hour thyroid uptake of $\mathrm{I}^{\mathbf{1 3 1}}$ did not increase. This result was not unexpected, however, since, during this period, renal clearances of iodide were also increased by the mannitol infusion. In contrast, the 24-hour uptake of the same dose of $\mathrm{I}^{131}$ was increased in all four patients. This increase reflected persistence of increased thyroid transfer and clearance rates while renal clearances were returning to normal following cessation of mannitol infusion.

During postdiuresis tests, thyroid $\mathrm{I}^{131}$ transfer rates were increased above control values in all eight patients, whereas renal iodide clearances had returned to approximately normal values. As might be expected, percentile uptakes of this dose of $\mathrm{I}^{131}$ were, in all patients, increased at 3 and 24 hours, as well as all other time periods at which measurements were made (Figure 1).

It may be reasonable to question whether increases in thyroid $\mathrm{I}^{131}$ uptake or iodide clearance rate truly indicate an increase in thyroid function when these occur in association with decreased plasma iodide concentration and when the absolute rate of iodine accumulation either remains normal or, as in the present studies, decreases. Certainly, it would be agreed that the thyroid gland in chronic iodine deficiency is hyperfunctioning, even though the absolute rate of hormone formation is not increased. It might be supposed, however, that acutely the thyroid always accumulates a constant quantity of iodide, so that iodide clearance varies acutely and inversely with changes in plasma iodide concentration. This question has been the subject of several investigations (11, 12, 39). From these studies it is clear that such an obligatory reciprocity does not obtain, since moderate or fairly marked acute increases in the plasma iodide concentration can be sustained without leading to de- creased $\mathrm{I}^{131}$ uptake or thyroid iodide clearance $(11,12)$.

On the other hand, the present findings seem clearly to indicate that the thyroid does respond with hyperfunction to procedures that acutely lower plasma iodide concentration. The data further suggest that this response is $a$ ) initiated by iodide depletion per se, and $b$ ) mediated within the thyroid itself, rather than the pituitary gland. With regard to the former conclusion, it is apparent that the low-iodine diet or the sustained osmotic diuresis might lead to changes in cellular hydration or electrolyte concentration that could alter thyroid function. Although minor variations in serum electrolyte concentrations were evident during mannitol infusion, all (i.e., sodium, potassium, chloride, $\mathrm{CO}_{2}$, and calcium) had returned to normal by the following morning, when the postdiuresis tests were performed. It seems unlikely that the increased thyroid transfer and clearance rates were due to an osmotic effect per se, since the isolated cat thyroid perfused with mannitol displays decreased iodine accumulation (40). The most important evidence that the thyroidal hyperfunction induced by the experimental procedure resulted from iodide depletion per se, however, was the finding that the increase in function, earlier demonstrated in the same patients, could be forestalled by including in the mannitol infusion only $800 \mu \mathrm{g}$ of sodium iodide (Figure 1). This quantity of iodide, even when given as a single dose, does not normally decrease thyroid clearance or $\mathrm{I}^{131}$ uptake and would not be expected to prevent an increase in thyroid function produced by the experimental procedure, unless this were due to iodide lack (11).

There is also strong reason to believe that the increased thyroid function induced by iodide depletion was not caused by an increased secretion of TSH, but rather represented an intrinsic response within the thyroid. Presumably, an increased secretion of TSH would be induced, not by iodide depletion per se, but by decreased hormonal delivery to the tissues. One would not expect a lowering of serum PBI from the present procedures, even if new hormone formation were completely prevented, since the glandular pool of preformed hormone is so large. Even full blocking doses of methimazole fail to lower the PBI of euthyroid subjects significantly within a period 
of a few days (33). A slight lowering of the PBI, averaging $0.5 \mu \mathrm{g}$ per $100 \mathrm{ml}$ and probably due to an expansion of the extracellular fluid volume, was evident during the diuretic test. Possibly, this may have been sufficient to stimulate TSH release. This seems unlikely, however, for several reasons. First, such stimulation could not have accounted for the increased thyroid clearances found during mannitol infusion, since the latent period of increased iodine accumulation following exogenous TSH in man is approximately 8 hours (41). Second, although PBI on the day after mannitol infusion were once again normal, they were not increased, as might have been expected if secretion of TSH had been increased. Finally, the inclusion of iodide in the mannitol infusion should not have forestalled an increase in thyroid function had this been due to increased secretion of TSH.

For the foregoing reasons, it would appear that acute depletion of extracellular iodide in man is associated with an intrinsic, autoregulatory increase in thyroid function, which tends to minimize the decreased hormonal synthesis that would otherwise occur. How this response is initiated and the precise steps in glandular iodine metabolism that are affected are at present uncertain.

\section{Summary}

Acute depletion of extracellular iodide has been achieved in eight patients, including two with diffuse toxic goiter, by institution of a low-iodine diet, followed 24 hours later by an infusion of mannitol to increase renal clearance of iodide. Measurements of plasma iodide ( $\mathrm{I}^{127}$ ) concentration, thyroid $\mathrm{I}^{131}$ transfer and clearance rates, renal $\mathrm{I}^{131}$ clearance rate, absolute iodine $\left(\mathrm{I}^{127}\right)$ accumulation rate, and serum protein-bound iodine were made before, during (four patients), and 24 hours after mannitol infusion. This iodide depletion procedure resulted in decreased plasma iodide concentration, increased thyroid transfer and clearance rates, increased uptake of $\mathrm{I}^{131}$, and decreased absolute iodine accumulation. These changes, which were usually evident during the mannitol infusion, were uniformly present by the following day. Serum protein-bound iodines varied only slightly from control values. Decreases in plasma iodide concentration were prevented by inclusion of only $800 \mu \mathrm{g}$ of sodium iodide in the mannitol infusion, and, under these conditions, the increase in $\mathrm{I}^{\mathbf{1 3 1}}$ clearance and uptake did not occur.

It is concluded that there exists a mechanism for acutely increasing thyroid function in response to a relatively abrupt decrease in plasma iodide concentration. This mechanism apparently is not mediated by the pituitary, but resides within the thyroid gland itself.

\section{References}

1. Pitt-Rivers, R., and J. R. Tata. The Thyroid Hormones. London, Pergamon, 1961.

2. Werner, S. C., Ed. Thyrotropin. Springfield, Ill., Charles C Thomas, 1963.

3. Goldberg, R. C., R. O. Greep, and L. B. Nay, Jr. Modification of thyroid activity in absence of the anterior pituitary gland. Proc. Soc. exp. Biol. (N. Y.) $1953,84,621$.

4. Chapman, A. The relation of the thyroid and the pituitary glands to iodine metabolism. Endocrinology 1941, 29, 680 .

5. Halmi, N. S., and B. N. Spirtos. Analysis of the action of propylthiouracil on the pituitary-thyroid axis of rats. Endocrinology 1954, 55, 613.

6. Halmi, N. S. Regulation of the rat thyroid in short-term iodine deficiency. Endocrinology 1954, 54, 216.

7. VanderLaan, W. P., and R. Caplan. Observations on a relationship between total iodine content and the iodide-concentrating mechanism of the thyroid gland of the rat. Endocrinology 1954, 54, 437.

8. Halmi, N. S., and B. N. Spirtos. Analysis of the modifying effect of dietary iodine levels on the thyroidal response of hypophysectomized rats to thyrotrophin. Endocrinology 1955, 56, 157.

9. Braverman, L. E., and S. H. Ingbar. Changes in thyroidal function during adaptation to large doses of iodide. J. clin. Invest. 1963, 42, 1216.

10. Halmi, N. S., and R. G. Stuelke. Problems of thyroidal self-regulation. Metabolism 1956, 5, 646.

11. Feinberg, W. D., D. L. Hoffman, and C. A. Owen, Jr. The effects of varying amounts of stable iodide on the function of the human thyroid. J. clin. Endocr. 1959, 19, 567.

12. Wagner, H. N., Jr., W. B. Nelp, and J. H. Dowling. Use of neutron activation analysis for studying stable iodide uptake by the thyroid. J. clin. Invest. 1961, 40, 1984.

13. Koutras, D. A., W. D. Alexander, R. McG. Harden, and $E$. Wayne. Effect of small iodine supplements on thyroid function in normal individuals. $\mathrm{J}$. clin. Endocr. 1964, 24, 857.

14. Stanbury, J. B., G. L. Brownell, D. S. Riggs, H. Perinetti, J. Itoiz, and E. B. Del Castillo. En- 
demic Goiter: The Adaptation of Man to Iodine Deficiency. Cambridge, Harvard University Press, 1954.

15. Alexander, W. D., D. A. Koutras, J. Crooks, W. W. Buchanan, E. M. Macdonald, M. H. Richmond, and E. J. Wayne. Quantitative studies of iodine metabolism in thyroid disease. Quart. J. Med. 1962, 31, 281.

16. De Visscher, M., C. Beckers, H.-G. Van Den Schrieck, M. De Smet, A. M. Ermans, H. Galperin, and P. A. Bastenie. Endemic goiter in the Uele region (Republic of Congo). I. General aspects and functional studies. J. clin. Endocr. 1961, 21, 175.

17. Barakat, R. M., and S. H. Ingbar. Induction of acute iodine depletion and the response thereto in normal subjects and in patients with Graves' disease (abstract). J. clin. Invest. 1962, 41, 1343.

18. Bricker, N. S., and C. J. Hlad, Jr. Observations on the mechanism of the renal clearance of $\mathrm{I}^{131}$. J. clin. Invest. 1955, 34, 1057.

19. Ingbar, S. H. Simultaneous measurement of the iodide-concentrating and protein-binding capacities of the normal and hyperfunctioning human thyroid gland. J. clin. Endocr. 1955, 15, 238.

20. Myant, N. B., E. E. Pochin, and E. A. G. Goldie. The plasma iodide clearance rate of the human thyroid. Clin. Sci. 1949, 8, 109.

21. Berson, S. A., R. S. Yalow, J. Sorrentino, and B. Roswit. The determination of thyroidal and renal plasma $\mathrm{I}^{131}$ clearance rates as a routine diagnostic test of thyroid dysfunction. J. clin. Invest. $1952,31,141$.

22. Ingbar, S. H. The effect of cortisone on the thyroidal and renal metabolism of iodine. Endocrinology 1953, 53, 171.

23. Berson, S. A., and R. S. Yalow. The iodide trapping and binding functions of the thyroid. $\mathrm{J}$. clin. Invest. 1955, 34, 186.

24. Higgins, H. P. The ten-minute uptake of $I^{181}$ : a clinical study and comparison with other tests of thyroid function. J. clin. Endocr. 1959, 19, 557.

25. Owen, C. A., Jr., R. S. McCants, and W. M. McConahey. Abbreviation of Berson technic for estimation of thyroidal clearance of plasma radioiodide: use of Berson test to recognize thyroidal protein-binding defects. J. clin. Invest. 1960, 39, 790.

26. Thomas, I. D., T. H. Oddie, and J. Myhill. A diagnostic radioiodine uptake test in patients receiving antithyroid drugs. J. clin. Endocr. 1960, 20, 1601.

27. Stanley, M. M. The direct estimation of the rate of thyroid hormone formation in man. The effect of the iodide ion on thyroid iodine utilization. J. clin. Endocr. 1949, 9, 941.

28. Benotti, J., and N. Benotti. Protein-bound iodine, total iodine, and butanol-extractable iodine by partial automation. Clin. Chem. 1963, 9, 408.

29. Snedecor, G. W. Statistical Methods Applied to Experiments in Agriculture and Biology, 4th ed. Ames, Iowa, Iowa State College Press, 1946.

30. Perry, W. F., and J. F. S. Hughes. The urinary excretion and thyroid uptake of iodine in renal disease. J. clin. Invest. 1952, 31, 457.

31. Reilly, W. A., K. G. Scott, G. L. Searle, and J. N. Castle. Iodide measurements in various functional states of the thyroid. Metabolism 1958, 7, 699.

32. Burrows, B. A., and J. F. Ross. The thyroidal uptake of stable iodine compared with the serum concentration of protein-bound iodine in normal subjects and in patients with thyroid disease. J. clin. Endocr. 1953, 13, 1358.

33. Ingbar, S. H., and N. Freinkel. Simultaneous estimation of rates of thyroxine degradation and thyroid hormone synthesis. J. clin. Invest. 1955, 34, 808.

34. Berson, S. A., and R. S. Yalow. Quantitative aspects of iodine metabolism. The exchangeable organic iodine pool, and the rates of thyroidal secretion, peripheral degradation and fecal excretion of endogenously synthesized organically bound iodine. J. clin. Invest. 1954, 33, 1533.

35. Rosenberg, I. N., J. C. Athans, and A. Behar. Effect of thyrotropin on the release of iodide from the thyroid. Endocrinology 1960, 66, 185.

36. Nagataki, S., K. Shizume, and S. Okinaka. Effect of thyrotrophin on the metabolism of iodide $^{131}$ in the thyroid gland. Endocrinology 1961, 69, 199.

37. Burrows, B. A., D. W. Slingerland, A. Liuzzi, E. S. Dell, and D. E. Graham. Thyroidal iodide secretion. J. clin. Invest. 1960, 39, 975.

38. Alexander, W. D., M. T. Harrison, R. McG. Harden, and D. A. Koutras. The effect of total fasting on thyroid function in man. Metabolism 1964, 13, 587.

39. Alexander, W. D., D. A. Koutras, R. McG. Harden, and $\mathrm{E}$. Wayne. Iodine and thyroidal function: physiological significance of the plasma inorganic iodine. J. clin. Endocr. 1964, 24, 851.

40. Boatman, J. B., J. M. Walsh, and M. J. Rabinovitz. Hyperosmotic effects on the cat thyroid perfused in vitro. Amer. J. Physiol. 1959, 197, 1035.

41. Stanley, M. M., and E. B. Astwood. The response of the thyroid gland in normal human subjects to the administration of thyrotropin, as shown by studies with I ${ }^{132}$. Endocrinology 1949, 44, 49. 